\title{
Anatomical and histochemical descriptions of the male reproductive system of Diachasmimorpha longicaudata (Ashmed) (Hymenoptera: Braconidae)
}

\author{
Maria das Dores da Cruz Souza ${ }^{*}$ (D), Max Pereira Gonçalves², \\ Edmilson Amaral de Souza ${ }^{3}$, Wellen Oliveira Batista ${ }^{1}$, \\ Teresinha Augusta Giustolin ${ }^{1}$, Carlos Gustavo da Cruz ${ }^{1,4}$, \\ Clarice Diniz Alvarenga ${ }^{1}$
}

${ }^{1}$ Universidade Estadual de Montes Claros (UNIMONTES), Janaúba, MG, Brasil.

${ }^{2}$ Universidade Federal dos Vales do Jequitinhonha e Mucuri (UFVJM), Janaúba, MG, Brasil.

${ }^{3}$ Universidade Federal de Viçosa (UFV), Instituto de Ciências Biológicas e da Saúde, Rio Paranaíba, MG, Brasil.

${ }^{4}$ Universidade Federal de Uberlândia (UFU), Uberlândia, MG, Brasil.

\section{A R T I C L E I N F O}

\section{Article history:}

Received 25 June 2021

Accepted 26 August 2021

Available online 24 October 2021

Associate Editor: Juliano Morimoto

\section{Keywords:}

Histology

Spermatogenesis

Accessory glands

Seminal vesicles

Histochemistry

\begin{abstract}
A B S T R A C T
The parasitoid Diachasmimorpha longicaudata is an important control agent for several species of fruit flies. Research on the characteristics of the reproductive system and reproductive biology of this parasitoid can be valuable for studies in taxonomy and phylogeny of insects of the order Hymenoptera. In this study we analyzed the histology and histochemistry of the male reproductive system of D. longicaudata. In this species the male reproductive system consists of a pair of testes, two accessory glands, and an ejaculatory duct. Each testicle consists of only one follicle. The testicular follicles are filled with cysts in different stages of spermatogenesis. Histochemical analyses detected proteins and carbohydrates in the cytoplasm of secretory cells and in the lumen of accessory glands. The morphology of the male reproductive system of $D$. longicaudata differs in some respects from other species of Hymenoptera.
\end{abstract}

\section{Introduction}

Hymenoptera is one of the four largest insect orders with approximately 115.000 described species (Sharkey, 2007). This order has great ecological and economic importance, is represented by phytophagous insects, predators and parasitoids. Braconidae is one of the most numerous and important families within the order Hymenoptera, representing the second largest family, with about 19.000 described species (Yu, 2021). Braconids form one of the most studied groups of parasitoids, as they have a large number of species with potential to be used in biological pest control programs (Fernandez and Sharkey, 2006).

The parasitoid wasp Diachasmimorpha longicaudata (Ashmed) (Hymenoptera: Braconidae) is one of the most important species used in biological control of fruit flies worldwide (Montoya et al., 2000; González et al., 2007; López et al., 2009; Meirelles et al., 2016). This

\footnotetext{
*Corresponding author.

E-mail: souza.maria302@hotmail.com (M.D.C. Souza).
}

braconid parasitizes second and third-instar larvae of fruit flies of the family Tephritidae (Van Nieuwenhove and Ovruski, 2011). It was introduced into Brazil by Embrapa Mandioca e Fruticultura Tropical in 1994, aiming to control Anastrepha spp. and Ceratitis capitata (Wiedemann) (Diptera: Tephritidae) (Carvalho, 2005).

Diachasmimorpha longicaudata has excelled in augmentative-release programs for control of fruit flies of the genera Bactrocera, Anastrepha and Ceratitis (Carabajal-Paladino et al., 2010). Mass-rearing of this parasitoid in the laboratory is necessary to carry out augmentative releases. Therefore, knowledge of the characteristics of its reproductive system and reproductive biology can be valuable for the success of biological-control programs, as it would help to optimize production of this control agent in the laboratory.

The male reproductive system in Hymenoptera, in general, is formed by a pair of testicles, two seminal vesicles, a pair of deferent ducts, and a pair of accessory glands that connect to the deferent duct, 
forming the ejaculatory duct (Moreira et al., 2008; Araújo et al., 2010; Chapman, 2013). Within this general pattern, structural variations in the morphology of the hymenopteran reproductive system occur, and have served as a source of phylogenetic information (Dallacqua and Cruz-Landim, 2003; Tavares et al., 2003; Ferreira et al., 2004). These variations can occur in the number or size of the structures, in the absence of any of them, or in their position along the reproductive system (Moreira et al., 2008). In some cases, for example, the number of follicles per testicle may vary from one, which may occur in Braconidae, Chalcidoidea and Ichneumonidae (Huang et al., 2007; Fiorillo et al., 2008; Moreira et al., 2010; Uzbekov et al., 2017) to four, in most species of Apinae, Mellitinae and Megachilinae (Ferreira et al., 2004; Araújo et al., 2005). Other variations may also occur, such as the duration of sexual maturation, the number of spermatozoa per cyst, and the presence and number of accessory glands (Moreira et al., 2008).

Although there are studies on the morphology, anatomical, histology and ultrastructure characteristics of the male reproductive system of several species of Hymenoptera (Ferreira et al., 2004; Moreira et al., 2008, 2010; Araújo et al., 2010; Gomes et al., 2012; Moreira et al., 2012), few studies have been carried out on the morphology, histology and ultrastructure description of the male reproductive system of species of Braconidae (Maetô, 1987; Huang et al., 2007; Uzbekov et al., 2017).

No study has examined the morphology of the male reproductive system of $D$. longicaudata, which can contribute to knowledge of the reproductive biology and the success of this biological-control agent, and provide useful information for future studies of the taxonomy and phylogeny of Hymenoptera. The present study describes the anatomy and histology of the male reproductive system of the parasitoid $D$. longicaudata.

\section{Materials and methods}

\section{Obtaining insects}

Parasitoids and hosts used in this study were obtained from the Biological Control Laboratory of the State University of Montes Claros, Minas Gerais, Brazil, where these species are reared under controlled conditions (temperature $26 \pm 2{ }^{\circ} \mathrm{C}, \mathrm{RH} 65 \pm 10 \%$ and photophase $12 \mathrm{~h}$ ).

Larvae of Ceratitis capitata were used to maintain the colony of D. longicaudata. To the female parasitoids were offered hosts for $24 \mathrm{~h}$, through an oviposition device that consisted of an embroidery ring 10 $\mathrm{cm}$ in diameter and $0.8 \mathrm{~cm}$ high, supporting a voile sandwich. Inside this sandwich were $C$. capitata larvae (third instar) and a small amount of artificial diet. After exposure to the parasitoids, the host larvae were transferred to plastic containers containing moist vermiculite and covered with voile to allow ventilation, until the parasitoids emerged. The emerged parasitoids were placed in acrylic cages $(29.5 \mathrm{~cm} \times 29.5$ $\mathrm{cm} \times 29.5 \mathrm{~cm}$ ) and fed on artificial diet based on honey and water, following the method proposed by Carvalho et al. (1998).

\section{Light microscopy}

In order to analyze and describe the morphology of the male reproductive system of $D$. longicaudata, 30 individuals 6 days old, were dissected in $0.1 \mathrm{M}$ sodium phosphate buffer solution, $\mathrm{pH}$ 7.2, under a stereomicroscope (Leica EZ4 HD). Then, the reproductive systems were transferred to a glass container containing Zamboni fixative solution and kept in a refrigerator for $24 \mathrm{~h}$ (Stefanini et al., 1967). After this period, they were dehydrated in increasing ethanol concentrations (70\%, $80 \%, 90 \%$ and $95 \%$ ), for $15 \mathrm{~min}$ in each concentration. The dehydrated material was placed in plastic microtubes with a capacity of $1.5 \mathrm{ml}$, and the historesin solution (Leica) was added. The material in these microtubes was refrigerated for $24 \mathrm{~h}$ to allow infiltration of the resin. After this period, the material was transferred to a histomold to add historesin and the hardener in a 15: 1 ratio (historesin: hardener), and then transferred to an oven at $60^{\circ} \mathrm{C}$ for $48 \mathrm{~h}$, for complete polymerization. The dried material was glued to a small wooden block and sections $2 \mu \mathrm{m}$ thick were cut with a self-advancing rotary ultamicrotome (Leica RM2255), using glass knives. The sections were transferred to histological slides and stained with toluidine blue for $15 \mathrm{~min}$. The slides were assembled with coverslips, using Permount ${ }^{\mathrm{TM}}$ medium, to be analyzed and photographed.

The histochemical analyses were performed with the Xylidine Ponceau test (Vidal, 1970) to identify proteins, and the Periodic Acid Schiff-PAS test (O'Brien and McCully, 1981) to identify neutral polysaccharides. Photographic documentation for the anatomical and histochemical analyses was performed under a light microscope, model OPTICAM 400S, with an OPTICAM 100 camera coupled.

\section{Results}

The male reproductive system of $D$. longicaudata consists of a pair of testes connected to two deferent ducts, a pair of seminal vesicles, two accessory glands, and an ejaculatory duct (Figs. 1A and B).

Part of each deferent duct is differentiated into an enlarged region, which constitutes the seminal vesicle, where spermatozoa are stored until copulation. The deferent duct is connected in the median part of the accessory glands, and they later join together to form the ejaculatory duct, which is connected to the external genitalia, the aedeagus (Fig. 1B).

In this species, the testes have an ovoid shape and the two can be together, with the deferent ducts and their respective seminal vesicles covered by a single capsule of connective tissue (Fig. 2A). They can also be separated, that is, each testicle with the deferent duct and seminal vesicle is encapsulated separately, forming two units (Fig. 2B).

Each testis consists of only one follicle (Fig. 3A). Testicular follicles are filled with cysts at different stages of spermatogenesis and each cyst is surrounded by non-germ cells (Figs. 3D and E). In each cyst, all germ cells are at the same stage of spermatogenesis. It is possible to observe cysts with cells in the spermatocyte phase (Fig. 3B), spermatogonia (Fig. 3C), spermatids in bundles (Fig. 3D) and already mature spermatozoa (Fig. 3E).

In the follicles the germ cells are organized into cysts. A considerable variation was found in the number of spermatozoa per cyst, which ranged from 64 to 150 (Fig. 3E). After maturation, the spermatozoa, already free, leave the testicles and migrate to the seminal vesicles, where they are stored until they are transferred to the females (Figs. 4A and B). The fact that the spermatozoa already arrive free in the seminal vesicles and not in bundles, is evidenced by the presence of individualized spermatozoa inside the deferent ducts (Fig. 4C).

The epithelium of the deferent ducts, through which spermatozoa leave the testes, is formed by squamous cells (Fig. 4C). The seminal vesicles are tubular, have lumen completely filled with free spermatozoa, and their walls are composed of simple epithelial tissue with pavement cells (Figs. 4A and B).

The accessory glands are connected to the ejaculatory duct and are well developed. They are tubular and consist of pavement epithelial cells, and the lumen is filled with a granular secretion (Figs. 5A and D). The accessory gland walls have a large amount of secretory vesicles (Fig. 5C). The histochemical test (Xylidine Ponceau) showed the presence of proteins in the cytoplasm of the secretory cells, as well as in the secretion of the lumen of the accessory glands (Figs. 5A-C). The PAS test was positive for the secretion of the lumen and for the substances present in the apical region of the secretory cells (Figs. 5D and E). 

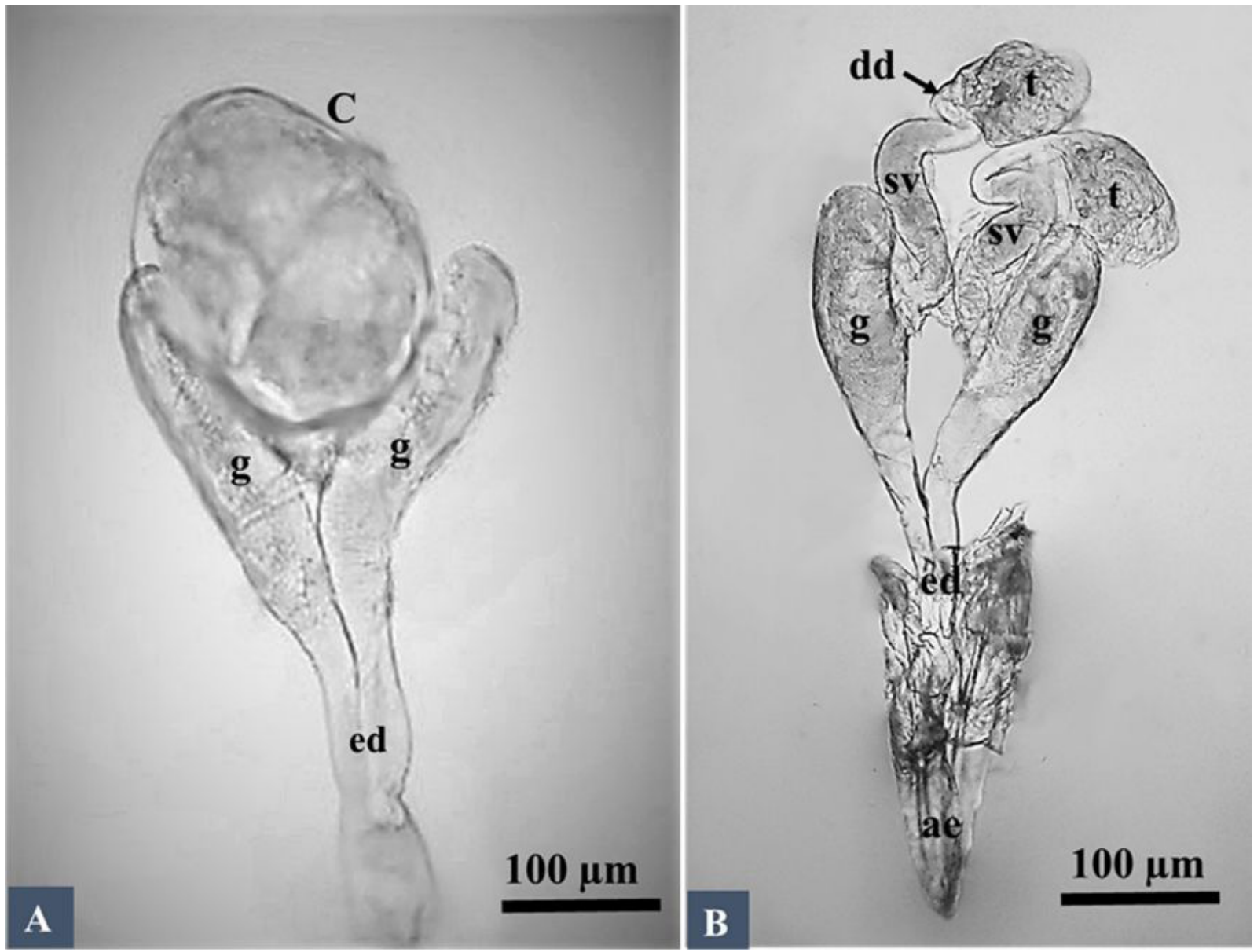

Figure 1 Photomicrograph of the male reproductive system of Diachasmimorpha longicaudata. A. The testes and seminal vesicles are surrounded by the capsule (c), accessory gland (g), ejaculatory duct (ed), B. testicles after capsule rupture. Testis ( $\mathrm{t}$ ), deferent duct (dd), seminal vesicle (sv), accessory glands (g), ejaculatory duct (ed) and aedeagus (ae).

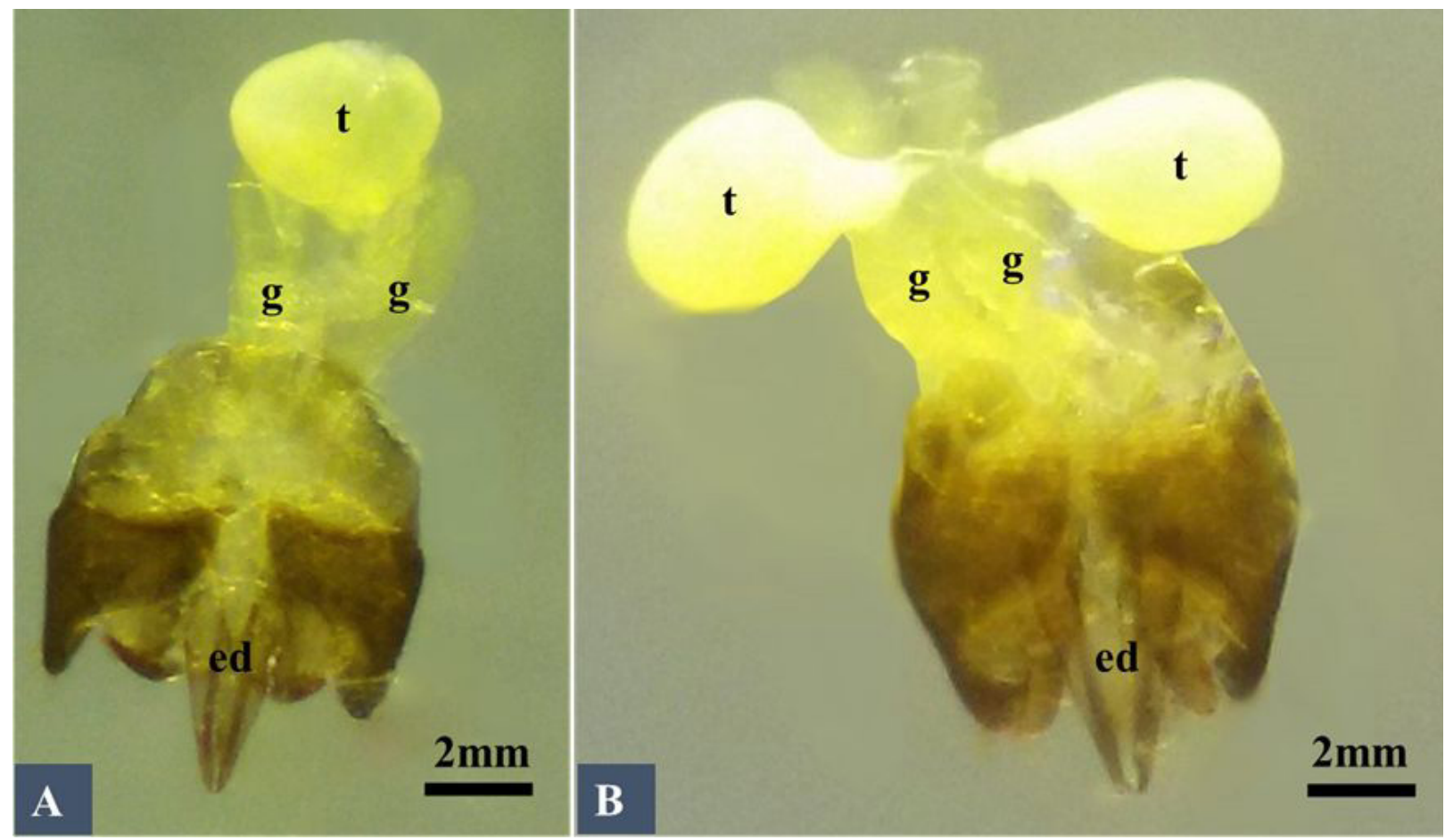

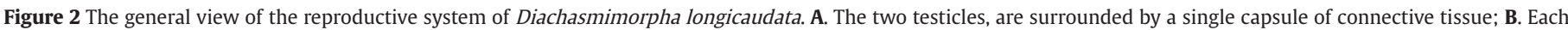
testicle, seminal vesicle and deferent duct are encapsulated separately. Testicle (t), accessory glands ( $\mathrm{g}$ ), ejaculatory duct (ed). 

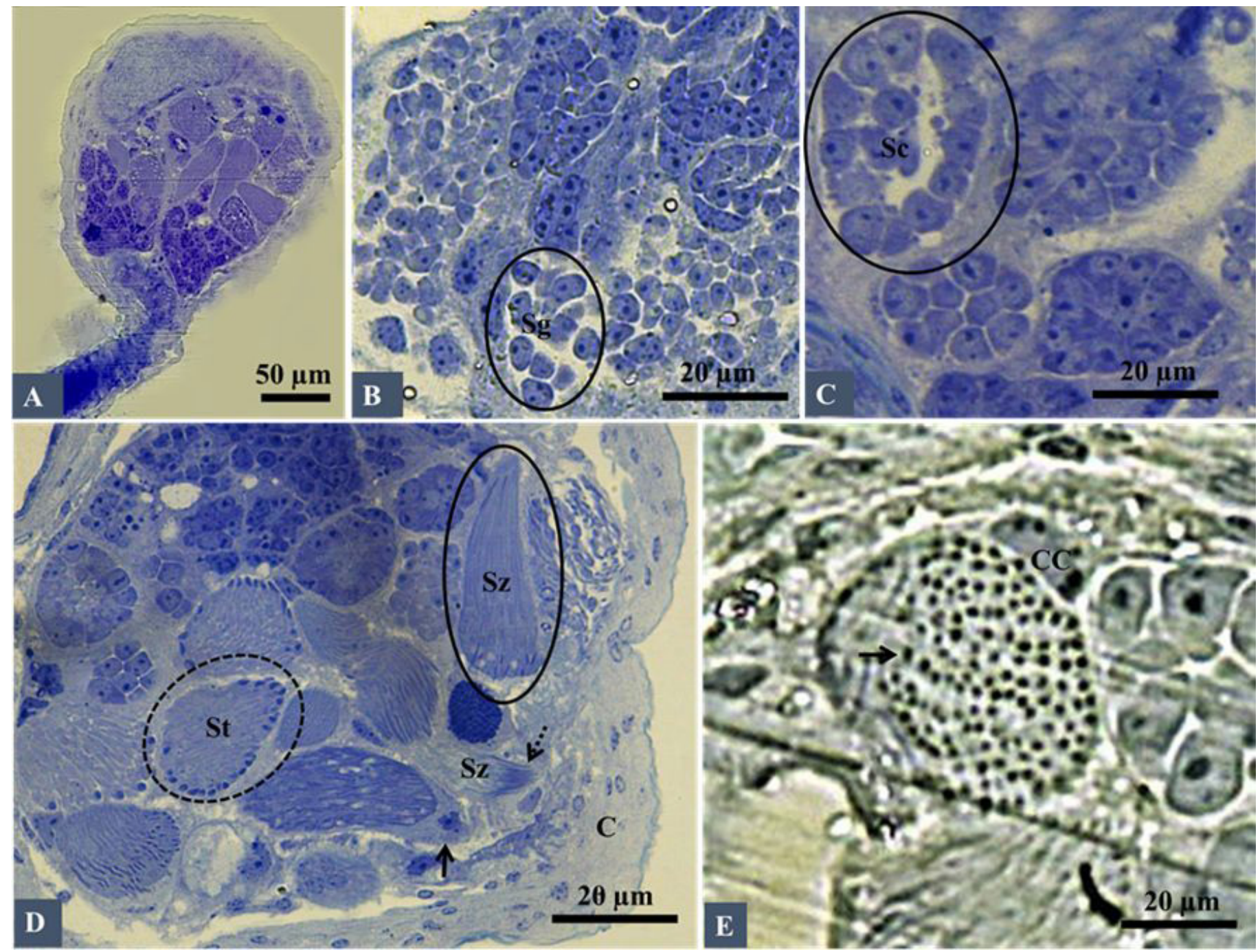

Figure 3 Histology of the male reproductive system of Diachasmimorpha longicaudata. A. Longitudinal section of the testicle, showing the presence of only one follicle. B. Germarium region with spermatogonia from the testicular follicle (circle). Spermatogonia (Sg). C. Cysts with spermatocytes in the testicular follicle growth zone (circle). Spermatocytes ( $\mathrm{Sc}$ ). D. Testicular follicle with cysts at different stages of spermatogenesis: Cystic cell (arrow continues), spermatids (dashed circle), spermatozoa in bundles with elongated shape (continuous circle), spermatozoa bundles (dotted arrow), conjunctiva capsule (C). Spermatids (St); Spermatozoa (Sz). E. Cyst containing mature spermatozoa (arrow), cystic cell nucleus (CC).

\section{Discussion}

The general morphology of the male reproductive system of the parasitoid $D$. longicaudata is similar to other species of Braconidae (Huang et al., 2007; Uzbekov et al., 2017), characterized by the presence of a pair of testicles, two deferent ducts, and two seminal vesicles, followed by two well-developed accessory glands and an ejaculatory duct.

Here, we observed that $D$. longicaudata can present the two testicles together, covered by a single capsule of connective tissue, or they can be encapsulated separately. This characteristic has not yet been reported in the literature for any species of parasitoid Braconidae or in the order Hymenoptera. In Cotesia vestalis (Haliday) (Hymenoptera, Braconidae) and Cotesia congregata Say (Hymenoptera, Braconidae) each testicle and the seminal vesicles are involved separately by the conjunctive capsule (Huang et al., 2007; Uzbekov et al., 2017). Ferreira et al. (2004) reported variations in the morphology of the male reproductive system among several species of bees, even being from the same family.

The morphology of the male reproductive system of Hymenoptera differs considerably among species. These differences may be related to the presence, size or shape of the structures, as well as their position along the reproductive tract (Ferreira et al., 2004; Araújo et al., 2005; Bushrow et al., 2006; Moreira et al., 2008; Chapman, 2013).

The number of follicles per testicle may vary among the groups of Hymenoptera. In D. longicautada, only one follicle was observed in each testicle. Other studies of parasitic wasps have also reported only one follicle per testicle (Huang et al., 2007; Fiorillo et al., 2008; Moreira et al., 2010; Paoli et al., 2013; Uzbekov et al., 2017), which indicates that it is a common morphological characteristic among parasitoids. On the other hand, in bees the number of follicles can vary considerably. The presence of three follicles per testicle has been reported in bee species from the subfamilies Colletinae, Andreninae and Halictinae (Ferreira et al., 2004; Araújo et al., 2005), and in Crabronidae wasps (Moreira et al., 2008). In most species of the subfamilies Apinae, Mellitinae and Megachilinae, four follicles were observed (Ferreira et al., 2004; Araújo et al., 2005); exceptions were observed in Hypanthidium faveolatum (Alfken), with 28 follicles (Gracielle et al., 2009), and Apis melifera (Linnaeus) (Apidae), with about 250 follicles in each testicle (Chapman, 2013). Thus, within the order Hymenoptera, differences 

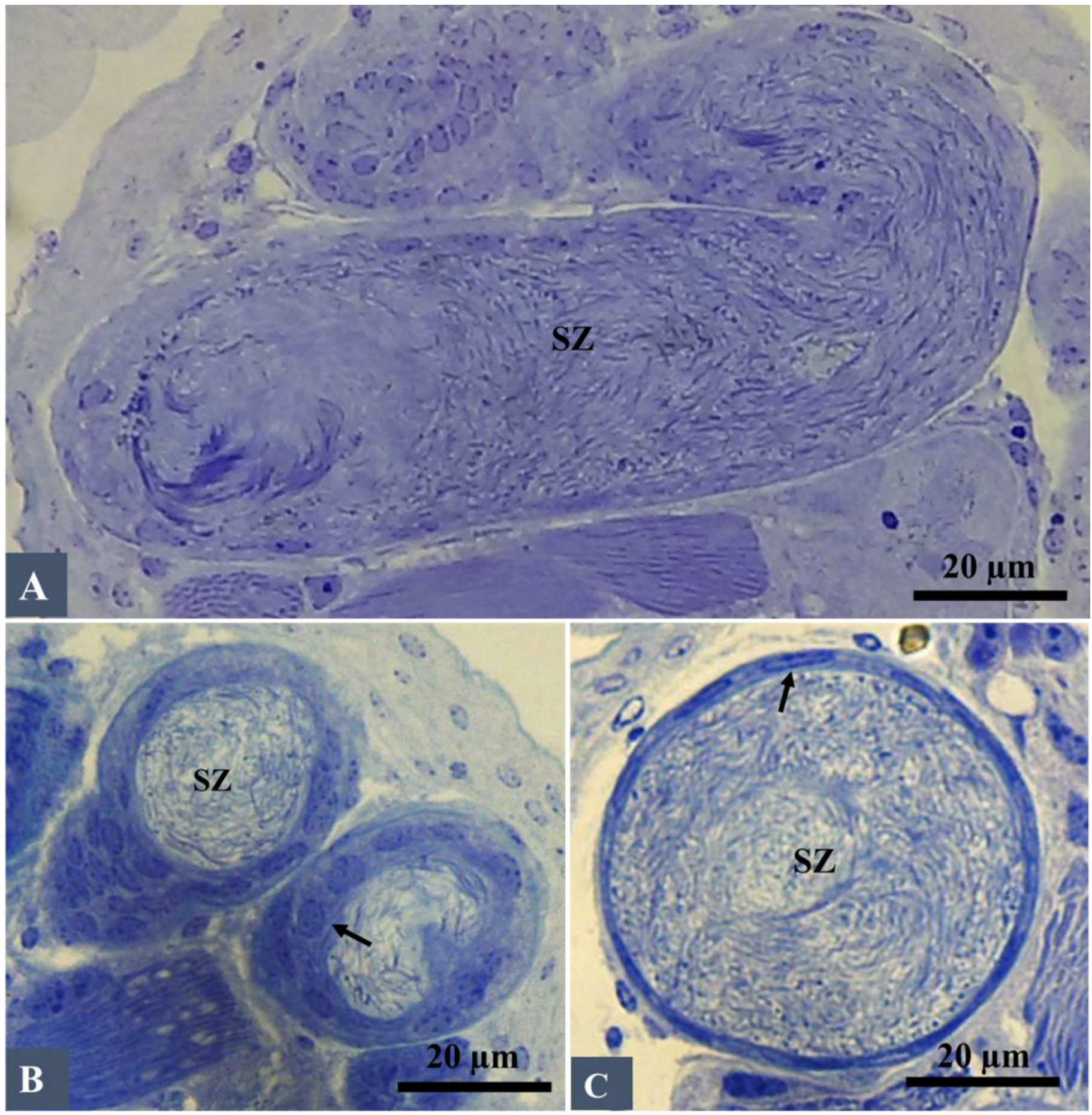

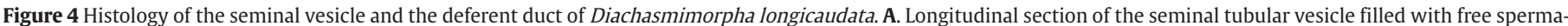

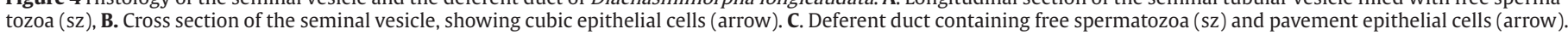

in the number of follicles in each testicle is a characteristic that can separate families (Ferreira et al., 2004).

The presence of cysts at different stages of spermatogenesis in the testicles of $D$. longicaudata indicates that spermatozoa production in this species is continuous, as spermatozoa production was observed both in newly emerged males (one day old) and at six days old. CarbajalPaladino et al. (2017) observed cysts at different stages of spermatogenesis in $D$. longicaudata aged 11 days. Continuous spermatozoa production generally occurs in species that have a long adult life and copulate throughout this phase (Buschini, 2007; Moreira et al., 2008). However, males that copulate for a short period produce spermatozoa only once, with the onset of spermatogenesis in the pupal phase, ending before or shortly after adult emergence (Boomsma et al., 2005; Lima et al., 2006). For example in several species of Hymenoptera, mainly social ones, males produce spermatozoa only once and then the testicles begin to degenerate immediately after the spermatozoa migrate to the seminal vesicles (Cruz-Landim and Dallacqua, 2002; Araújo et al., 2005; Lima et al., 2006). Species such as these can copulate many 


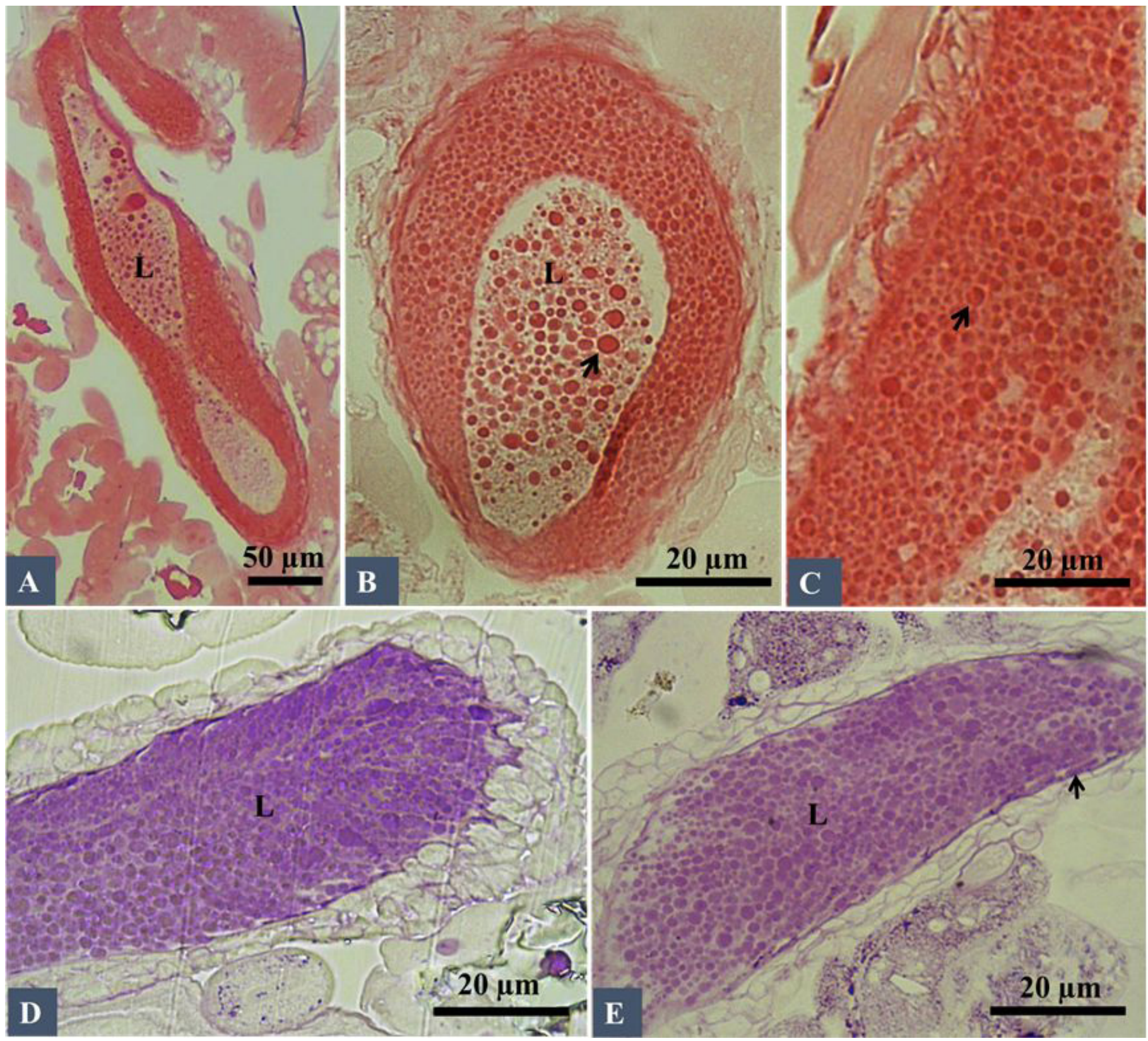

Figure 5 Histochemistry of the accessory glands of Diachasmimorpha longicaudata. A. Longitudinal section and B. cross section of the accessory gland stained with Xylidine Ponceau. Lumen (L), protein secretions (arrow). C. Accessory gland wall containing secretory vesicles (arrow). D and E. PAS. positive for secretions and substances present in the apical region of secretory cells, and pavement epithelial cells (arrow).

times, however, within short intervals, as they do not replenish the spermatozoa stock in the seminal vesicles (Baer, 2003).

Spermatogenesis occurs in the testicles, in compartments called cysts. In the present study, we observed cysts with cells in different stages of differentiation, that is, cysts with spermatogonia, spermatocytes and spermatids, with a more-elongated shape due to loss of cytoplasm, nuclear compaction and flagellar formation, which indicates maturation for the formation of spermatozoa. Other research reports a similar sequence of events in the male reproductive system of other insects orders, such as Coleoptera and Heteroptera (Ozyurt et al., 2015; Candan et al., 2018; Koçakoğlu et al., 2019, 2021). According to Chapman (2013), as the cysts are produced at the apex of the follicle, they displace those that developed previously, so that a series of developmental stages is present in each follicle, with the initial stages in the germ and the oldest in the proximal part of the follicle adjacent to the deferent duct.

The variation in the number of spermatozoa per cyst found in $D$. Iongicaudata (64 to 150) has also been observed in other hymenopterans. In the parasitic wasp Arge pagana (Panzer) (Symphyta), 240 to 350 spermatozoa were found per cyst (Lino-Neto et al., 2008). In the egg parasitoid Gryon pennsylvanicum (Ashmead) (Platygastridae) about 64 spermatozoa were found per cyst (Paoli et al., 2013). The presence of 64 spermatozoa per cyst has also been reported in euglossine bees (Zama et al., 2005) and Xylocopa frontalis (Olivier) (Fiorillo et al., 2010). According to Gomes et al. (2012), the plesiomorphic number of spermatozoa per cyst in Hymenoptera is 64, as also found in Trypoxylon (Trypargilum) Richards (Moreira et al., 2008) and Microstigmus arlei (Richards) (Zama et al., 2007). However, in some members of Vespidae 
up to 128 spermatozoa were observed (Brito et al., 2005), as in Polistes versicolor versicolor (Olivier) (Araújo et al., 2010), and in Apidae, tribe Meliponini (Lino-Neto et al., 2008). The number of spermatozoa per cyst is determined by the number of cell divisions and is constant for each species; however, it can vary from species to species. Therefore, this number has been used as supplementary information in the systematics of Hymenoptera (Zama et al., 2007; Lino-Neto et al., 2008).

When the spermatozoa are formed, the cysts rupture and the spermatozoa travel to the deferent ducts and then to the seminal vesicles, where they are stored until they are transferred to the females during copulation. We observed that in $D$. longicaudata, the spermatozoa leave the testicles individually and remain free in the seminal vesicles. This was evidenced by the presence of free spermatozoa in the deferent ducts. This characteristic has also observed in other species of Hymenoptera (Lino-Neto et al., 1999; Fiorillo et al., 2008; Moreira et al., 2010), including braconids (Uzbekov et al., 2017), all belonging to the group of parasitic wasps. It is believed that this characteristic may be common in parasitic wasps, as in these insects there is still no report of the occurrence of sperm bundles, either in the seminal vesicles or in the deferent ducts (Schiff et al., 2001). According to Lino-Neto et al. (2008), it is likely that the organization of sperm in bundles in seminal vesicles is an ancestral characteristic common to Hymenoptera, and its absence in parasitic wasps would be a more recent apomorphy. In most hymenopterans, the spermatozoa are released from the testicles in bundles. Aculeata release their sperm from the testicles in bundles and they separate only in the seminal vesicles (Cruz-Landim, 2001; Moreira et al., 2004; Zama et al., 2005). In Symphyta, the spermatozoa leave the testicles and remain in bundles in the seminal vesicle (Quicke et al., 1992; Schiff et al., 2001; Lino-Neto et al., 2008). According to Lino Neto et al. (2008), this difference may indicate that the seminal vesicle of members of Aculeata differs from that of Symphyta in its enzyme content and/ or the $\mathrm{pH}$ of fluids in the lumen.

In Hymenoptera, the seminal vesicles comprise an enlarged and differentiated region of the deferent ducts, usually the median region as observed in D. longicaudata. Most, but not all hymenopterans possess seminal vesicles (Moreira et al., 2010). In addition to storing spermatozoa, seminal vesicles can also have other functions, for example nourishing spermatozoa (Gillott, 2005; Chapman, 2013), especially in species that lack accessory glands. This is not the case for $D$. longicautada, which has well-developed accessory glands, formed by cells that contain secretory vesicles throughout their cytoplasm. As with the other organs of the reproductive system, the accessory glands have wide morphological diversity and may be tubular, spherical or oval. In some species, such as meliponine bees (Apidae), accessory glands are absent (Ferreira et al., 2004). Each accessory gland consists of a single layer of epithelial cells, which vary in structure depending on the stage of development and the nature of the secretion produced (Chapman, 2013).

The histochemical test Xylidine Ponceau and PAS of the accessory glands of $D$. longicautada indicated the presence of proteins and carbohydrates in the secretion of the lumen and in the secretory vesicles of cells, respectively. Proteins and carbohydrates have also been found in the accessory glands of other insect species, as the main components of glandular secretion (Marchini et al., 2003; Fernandez and Cruz-Landim, 2004; Cruz-Landim and Dallacqua, 2005; Gillott, 2005; Braswell et al., 2006).

The accessory glands become functional in the early adult life of the insect, and the secretions they produce are transferred to the females along with the spermatozoa during copulation (Gillott, 2005; Chapman, 2013). These secretions have several functions, including induction and acceleration of oviposition, increased fertility, decreased female receptivity or attractiveness, maintenance and activation of spermatozoa, and success in sperm competition (Gillott, 2005; Huang et al., 2007;
Avila et al., 2011; King et al., 2011). These secretions may also be related to the male reproductive strategy, contributing to the mechanism that guarantees copulation fidelity and keeps the sperm viable in the female's spermateca for a longer period (Araújo et al., 2010).

It is clear that the male reproductive system of $D$. longicaudata possesses morphological diversity capable of differentiating it from other species of Hymenoptera. An example is the organization of the testicles in the testicular capsule, in which the two may be enclosed by a single conjunctive capsule, or by separate capsules, forming two structures. The morphological characteristics of the male reproductive system of $D$. longicaudata for example the continuous production of spermatozoa, provide information about the reproductive behavior of this species. The diversity of information provided by the morphological characteristics of the reproductive system of this important biological control agent can be used in future studies of behavior, taxonomy and phylogeny of insects of the Hymenoptera group.

\section{Acknowledgements}

We thank to the Minas Gerais State Research Support Foundation (FAPEMIG) and the Coordination for the Improvement of Higher Education Personnel, Brazil (CAPES). We thank Janet Reid for valuable comments on english version of manuscript, whose comments and suggestions have improved the quality of our manuscript. We thank Dr. Maria Olívia for material provided.

\section{Funding}

Minas Gerais State Research Support Foundation (FAPEMIG) (CAG - APQ-02795-16).

Coordination for the Improvement of Higher Education Personnel, Brazil (CAPES) Finance Code 001.

\section{Conflicts of interest}

The authors declare no conflicts of interest.

\section{Author contribution statement}

MDCS: Investigation; Methodology; Data curation; Formal analysis; Writing - original draft; Writing - review \& editing. MPG: Conceptualization; Formal analysis; Writing - review \& editing. EAS: Investigation; Methodology; Writing - review \& editing. WOB: Investigation; Methodology. TAG: Writing - review \& editing. CGC: Investigation; Methodology. CDA: Conceptualization; Funding acquisition; Investigation; Methodology; Project administration; Data curation; Supervision; Writing - original draft; Writing - review \& editing.

\section{References}

Araújo, V. A., Freitas, F. V., Moreira, J., Neves, C. A., Lino-Neto, J., 2010. Morphology of male reproductive system of two solitary bee species (Hymenoptera: apidae). Neotrop. Entomol. 39 (4), 595-600. http:// dx.doi.org/10.1590/S1519-566X2010000400020.

Araújo, V. A., Zama, U., Neves, C. A., Dolder, H., Lino-Neto, J., 2005. Ultrastructural, histological and histochemical characteristics of the epithelial wall of the seminal vesicle of mature males of Scaptotrigona xanthotricha Moure (Hymenoptera, Apidae, Meliponini). Braz. J. Morphol. Sci. 22, 193-201. 
Avila, F. W., Sirot, L. K., Laflamme, B. A., Rubinstein, C. D., Wolfner, M. F., 2011. Insect seminal fluid proteins: identification and function. Annu. Rev. Entomol. 56 (1), 21-40. http://dx.doi.org/10.1146/ annurev-ento-120709-144823.

Baer, B., 2003. Bumblebees as model organisms to study male sexual selection in social insects. Behav. Ecol. Sociobiol. 54 (6), 521-533. http://dx.doi.org/10.1007/s00265-003-0673-5.

Boomsma, J. J., Baer, B., Heinze, J., 2005. The evolution of male traits in social insects. Annu. Rev. Entomol. 50 (1), 395-420. http://dx.doi. org/10.1146/annurev.ento.50.071803.130416.

Braswell, W. E., Andrés, J. A., Maroja, L. S., Harrison, R. J., Howard, D. J., Swanson, W. J., 2006. Identification and comparative analysis of accessory gland proteins in Orthoptera. Genome 49 (9), 1069-1080. http://dx.doi.org/10.1139/g06-061.

Buschini, M. L. T., 2007. Life-history and sex allocation in Trypoxylon (syn. Trypargilum) lactitarse(Hymenoptera; Crabronidae). J. Zool. Syst. Evol. Res. 45 (3), 206-213. http://dx.doi.org/10.1111/j.14390469.2006.00405.x.

Bushrow, E. S., Fuller, C. L., Cowan, D. P., Byrd, C. A., 2006. Anatomy of the male reproductive system and sperm morphology in the caterpillarhunting wasp Ancistrocerus antilope (Hymenoptera, Vespidae). Invertebr. Biol. 125 (4), 354-362. http://dx.doi.org/10.1111/j.17447410.2006.00067.x.

Brito, P., Moreira, J., Lino-Neto, J., 2005. Morphology of the male reproductive system and sperm of Mischocyttarus sp. (Hymenoptera: Vespidae: Polistinae). Braz. J. Morphol. Sci. 22 (Suppl.), 175-176.

Candan, S., Koçakoğlu, N. O., Suludere, Z., 2018. Morphological and histological structure of the male reproductive system of the water strider Gerris lacustres (Linnaeus 1758) (Gerridae, Heteroptera). Microsc. Res. Tech. 81 (7), 770-780. http://dx.doi.org/10.1002/ jemt.23035.

Carabajal-Paladino, L. Z., Papeschi, A. G., Cladera, J. L., 2010. Immature stages of development in the parasitoid wasp, Diachasmimorpha longicaudata. J. Insect Sci. 10 (56), 1-13. http://dx.doi.org/10.1673/031.010.5601.

Carbajal-Paladino, L. Z., Nostro, F. L., Papeschi, A., Cladera, J., Bressa, M. J., 2017. Spermatogenesis in the parasitoid Diachasmimorpha longicaudata (Hymenoptera: braconidae). Acta Zool. 98 (1), 38-43. http://dx.doi.org/10.1111/azo.12148.

Carvalho, R. S., 2005. Avaliação das liberações inoculativas do parasitoide exótico Diachasmimorpha longicaudata(Ashmead) (Hymenoptera: Braconidae) em pomar diversificado em Conceição do Almeida, BA. Neotrop. Entomol. 34 (5), 799-805. http://dx.doi.org/10.1590/ S1519-566X2005000500012.

Carvalho, R. S., Nascimento, A. S., Matrangolo, W.J. R., 1998. Metodologia de criação do parasitoide exótico Diachasmimorpha longicaudata (Hymenoptera: Braconidae), visando estudos em laboratório e em campo. Embrapa-CNPMF, Cruz das Almas, 16 pp. (Circular Técnica, 30).

Chapman, R. F., 2013. The Insects: Structure and Function, 5th ed. Cambridge University Press, Cambridge, UK.

Cruz-Landim, C., 2001. Organization of the cysts in bee (Hymenoptera, Apidae) Testis: number of spermatozoa per cyst. Iheringia Ser.Zool. 91, 183-189. https://doi.org/10.1590/S0073-47212001000200025.

Cruz-Landim, C., Dallacqua, R. P., 2002. Testicular reabsorption in adult males of Melipona bicolor bicolor Lepeletier (Hymenoptera, Apidae, Meliponini). Cytologia (Tokyo) 67, 145-151. https://doi.org/10.1508/ cytologia.67.145.

Cruz-Landim, C., Dallacqua, R. P., 2005. Morphology and protein patterns of honey bee drone accessory glands. Genet. Mol. Res. 4, 473-481.

Dallacqua, R. P., Cruz-Landim, C., 2003. Ultrastructure of the ducts of the reproductive tract of males of Melipona bicolor bicolor Lepeletier (Hymenoptera, Apinae, Meliponini). Anat. Histol. Embryol. 32, 276281. https://doi.org/10.1046/j.1439-0264.2003.00484.X.
Fernandez, F. C., Cruz-Landim, C., 2004. Aspectos morfológicos do aparelho reprodutor masculino de Achroia grisella (Lepidoptera: pyralidae). Biociencias 12, 78-87.

Fernandez, F., Sharkey, M.J.(Eds.), 2006. Introducción a los Hymenoptera de la Región Neotropical. Sociedad Colombiana de Entomología y Universidad Nacional de Colombia, Bogotá D.C., 893 pp.

Ferreira, A., Abdalla, F. C., Kerr, W. E., Cruz-Landim, C., 2004. Systematics, morphology and physiology. Comparative anatomy of the male reproductive internal organs of 51 species of bees. Neotrop. Entomol. 33 (5), 569-576. http://dx.doi.org/10.1590/S1519-566X2004000500005.

Fiorillo, B. S., Lino-Neto, J., Báo, S. N., 2008. Structural and ultrastructural characterization of male reproductive tracts and spermatozoa in fig wasps of the genus Pegoscapus (Hymenoptera, Chalcidoidea). Micron 39 (8), 1271-1280. http://dx.doi.org/10.1016/j.micron.2008.03.005.

Fiorillo, B., Zama, U., Lino-Neto, J., Báo, S. N., 2010. Structural and ultrastructural studies of male reproductive tract and spermatozoa in Xylocopa frontalis (Hymenoptera, Apidae). Acta Zool. 91 (2), 176183. http://dx.doi.org/10.1111/j.1463-6395.2009.00396.x.

Gillott, C., 2005. Entomology, 3rd ed. Springer, Dordrecht.

Gomes, L. F., Badke, J. P., Zama, U., Dolder, H., Lino-Neto, J., 2012. Morphology of the male reproductive system and spermatozoa in Centris Fabricius, 1804 (Hymenoptera: Apidae, Centridini). Micron 43 (6), 695-704. http://dx.doi.org/10.1016/j.micron.2012.01.013.

González, P. I., Montoya, P., Perez-Lachaud, G., Cancino, J., Liedo, P., 2007. Superparasitism in mass reared Diachasmimorpha longicaudata (Ashmead) (Hymenoptera: Braconidae), a parasitoid of fruit flies (Diptera: Tephritidae). Biol. Control 40 (3), 320-326. http://dx.doi. org/10.1016/j.biocontrol.2006.11.009.

Gracielle, I. M. S., Fiorillo, B. S., Lino-Neto, J., Báo, S. N., 2009. Morphology of the male reproductive system and spermiogenesis in Hypanthidium foveolatum (Alfken, 1930) (Hymenoptera: Apidae: Megachilinae). Micron 40 (4), 419-425. https://doi.org/10.1016/j.micron.2009.02.003.

Huang, F., Yu, R., Chen, X., 2007. Ultrastructure of the male reproductive system of Cotesia vestalis (Hymenoptera: Braconidae) with preliminary characterization of the secretions. Microsc. Res. Tech. 70 (7), 563-571. http://dx.doi.org/10.1002/jemt.20435.

King, M., Eubel, H., Millar, A. H., Baer, B., 2011. Proteins within the seminal fluid are crucial to keep sperm viable in the honeybee Apis mellifera. J. Insect Physiol. 57 (3), 409-414. http://dx.doi. org/10.1016/j.jinsphys.2010.12.011.

Koçakoğlu, N. O., Candan, S., Güllü, M., 2019. The histomorphological structure of the male reproductive system of maize leaf weevil Tanymecus dilaticollis Gyllenhal, 1834 (Coleoptera: curculionidae). Microsc. Res. Tech. 82 (8), 1345-1352. http://dx.doi.org/10.1002/ jemt.23286.

Koçakoğlu, N. O., Candan, S., Güllü, M., 2021. Anatomy and histology of reproductive system of adult male mint leaf beetle Chrysolina herbacea (Duftschmid, 1825) (Coleoptera: chrysomelidae). Microsc. Res. Tech. 84 (3), 512-520. http://dx.doi.org/10.1002/jemt.23607.

Lima, M. A. P., Lino-Neto, J., Campos, L. A. O., 2006. Sexual maturation in Melipona mondury males (Apidae: meliponini). Braz.J. Morphol. Sci. 23, 369-375.

Lino-Neto, L., Báo, S. N., Dolder, H., 1999. Structure and ultrastructure of the spermatozoa of Bephratelloides pomorum (Fabricius) (Hymenoptera: Eurytomidae). Int. J. Insect. Morphol. Embryol. 28 (4), 253-259. https://doi.org/10.1016/S0020-7322(99)00028-8.

Lino-Neto, J., Araújo, V. A., Dolder, H., 2008. Inviability of the spermatids with little cytoplasm in bees (Hymenoptera, Apidae). Sociobiology 51, 163-172. https://doi.org/10.1016/j.tice.2007.11.004.

López, O. P., Hénaut, Y., Cancino, J. P., Lambin, M., Cruz-López, L., Rojas, J. C., 2009. Is host size an indicator of quality in the mass-reared parasitoid 
Diachasmimorpha longicaudata (Hymenoptera: braconidae)? Fla. Entomol. 92 (3), 441-449. http://dx.doi.org/10.1653/024.092.0305.

Maetô, K., 1987. Comparative morphology of the male internal reproductive organs of the Family Braconidae (Hymenoptera Ichneumonoidea). Kontya 55, 32-42.

Marchini, D., Del Bene, G., Cappelli, L., Dallai, R., 2003. Ultrastructure of the male reproductive accessory glands in the medfly Ceratitis capitata (Diptera, Tephritidae) and preliminary characterization of their secretions. Arthropod Struct. Dev. 31 (4), 313-327. http:// dx.doi.org/10.1016/S1467-8039(03)00003-3.

Meirelles, R. N., Redaelli, L. R., Jahnke, S. M., Ourique, C. B., Ozorio, D. V. B., 2016. Parasitism of fruit flies (Tephritidae) in field, after the releases of Diachasmimorpha longicaudata(Ashmead) (Hymenoptera: Braconidae) in Rio Grande do Sul. Rev. Bras. Frutic. 38 (2), 673-683. http://dx.doi.org/10.1590/0100-29452016673.

Montoya, P., Liedo, P., Benrey, B., Cancino, J., Barrera, J. F., Sivinski, J., Aluja, M., 2000. Biological control of Anastrepha spp. (Diptera: Tephritidae) in mango orchards through augmentative releases of Diachasmimorpha longicaudata (Ashmead) (Hymenoptera: Braconidae). Biol. Control 18 (3), 216-224. http://dx.doi.org/10.1006/ bcon.2000.0819.

Moreira, J., Araújo, V. A., Báo, S. N., Lino-Neto, J., 2010. Structural and ultrastructural characteristics of male reproductive tract and spermatozoa in two Cryptinae species (Hymenoptera: ichneumonidae). Micron 41 (3), 187-192. http://dx.doi.org/10.1016/j.micron.2009.11.005.

Moreira, J., Brito, P., Mancini, K., Dolder, H., Lino-Neto, J., 2012. The descriptions of new microanatomical structures of the male reproductive system and sperm of Myschocyttarus cassununga (Hymenoptera: vespidae). Micron 43 (2-3), 292-297. http://dx.doi. org/10.1016/j.micron.2011.09.003.

Moreira, J., Zama, U., Lino-Neto, L., 2004. Release, behavior and phylogenetic significance of spermatozoa in bundles in the seminal vesicle during sexual maturation in Aculeata (Hymenoptera). Braz. J. Morphol. Sci. 21, 185-189.

Moreira, P. A., Araújo, V. A., Zama, U., Lino-Neto, J., 2008. Morphology of male reproductive system in three species of Trypoxylon(Trypargilum) Richards (Hymenoptera: crabronidae). Neotrop. Entomol. 37 (4), 429-435. http://dx.doi.org/10.1590/S1519-566X2008000400012.

O’Brien, T. P., McCully, M. E., 1981. The Study of Plant Structure: Principles and Selected Methods. Termarcarphi, Melbourne.

Ozyurt, N., Candan, S., Suludere, Z., 2015. Ultrastructure of Male Reproductive System of Eurydema ventrale Kolenati 1846 (Heteroptera: pentatomidae). Microsc. Res. Tech. 78, 643-653. https://doi.org/10.1002/jemt.22514.

Paoli, F., Gottardo, M., Dallai, R., Roversi, P. F., 2013. Morphology of the male reproductive system and sperm ultrastructure of the egg parasitoid Gryon pennsylvanicum (Ashmead) (Hymenoptera, Platygastridae). Arthropod Struct. Dev. 42, 297-308. https://doi. org/10.1016/j.asd.2013.03.005.

Quicke, D. L. J., Ingram, S. N., Baillie, H. S., Gaitens, P. V., 1992. Sperm structure and ultrastructure in the Hymenoptera (Insecta).Zool. Scr. 21, 381-402. https://doi.org/10.1111/j.1463-6409.1992.tb00339.x.

Schiff, N., Flemming, A. J., Quicke, D. L. J., 2001. Spermatodesmata of the sawflies (Hymenoptera: Symphyta): evidence for multiple increases in sperm bundle size. J. Hymenopt. Res. 10, 119-125.

Sharkey, M. J., 2007. Phylogeny and classification of Hymenoptera. Zootaxa 1668, 521-548. https://doi.org/10.11646/zootaxa.1668.1.25.

Stefanini, M., Demartino, C., Zamboni, L., 1967. Fixation of ejaculated spermatozoa for electron microscopy. Nature 216, 173-174.

Tavares, M. G., Irsigler, A. S. T., Campos, L. A. O., 2003. Testis length distinguishes haploid from diploid drones in Melipona quadrifasciata (Hymenoptera: meliponinae). Apidologie (Celle) 34 (5), 449-455. http://dx.doi.org/10.1051/apido:2003045.

Uzbekov, R., Burlaud-Gaillard, J., Garanina, A. S., Bressac, C., 2017. The length of a short sperm: Elongation and shortening during spermiogenesis in Cotesia congregata (Hymenoptera, Braconidae). Arthropod Struct. Dev. 46 (2), 265-273. http://dx.doi.org/10.1016/j. asd.2016.11.011.

Van Nieuwenhove, G. A., Ovruski, S. M., 2011. Influence of Anastrepha fraterculus (Diptera: Tephritidae) larval instars on the production of Diachasmimorpha longicaudata (Hymenoptera: Braconidae) progeny and their sex ratio. Fla. Entomol. 94 (4), 863-868. http:// dx.doi.org/10.1653/024.094.0421.

Vidal, B. C., 1970. Acid glycosaminoglycans and endochondral ossification: evaluation and macromolecular orientation. Nat. Rev. Mol. Cell Biol. 22, 45-64.

Yu, D. S. K. (2021). Taxapad Ichneumonoidea (version May 2009). In: Roskov, Y., Abucay, L., Orrell, T., Nicolson, D., Flann, C., Bailly, N., Kirk, P., Bourgoin, T., DeWalt, R.E., Decock, W., De Wever, A., (Eds.), Species 2000 \& ITIS Catalogue of Life 2016: Annual Checklist. Leiden. Available in: http://www.catalogueoflife.org/annual-checklist/2016/ details/database/id/68 (accessed 17 August 2021).

Zama, U., Lino-Neto, J., Mello, S., Campos, L. A. O., Dolder, H., 2005. Ultrastructural characterization of spermatozoa in euglossine bees (Hymenoptera, Apidae, Apinae). Insectes Soc. 52 (2), 122-131. http:// dx.doi.org/10.1007/s00040-005-0789-X.

Zama, U., Moreira, J., Báo, S. N., Campos, L. A. O., Dolder, H., Lino-Neto, J., 2007. Morphology of testicular and post-testicular spermatozoa in Microstigmus arlei Richards 1972 and M. nigrophthalmus Melo, 1992 (Hymenoptera, Apoidea, Pemphredoninae) with phylogenetic consideration. Arthropod Struct. Dev. 36 (3), 304-316. http://dx.doi. org/10.1016/j.asd.2006.11.004. 